\title{
XIII. Reflections on the new primary planet supposed to exist between Mars and Jupiter, and now in all probability discovered
}

\section{Baron Von Zach}

To cite this article: Baron Von Zach (1802) XIII. Reflections on the new primary planet supposed to exist between Mars and Jupiter, and now in all probability discovered, Philosophical Magazine Series 1, 12:45, 62-80, DOI: 10.1080/14786440208676026

To link to this article: http://dx.doi.org/10.1080/14786440208676026

曲 Published online: 18 May 2009.

Submit your article to this journal $[\pi$

Џll Article views: 2

Q View related articles $\longleftarrow$ 
may be, and to leave no doubt in regard to the obfervations, $I$ have again examined them; and in fome places which were rather uncertain, and which I employed in my firft calculations, I fubftituted others. I have alfo made an allowance for the deviation of the inftruments, and employed all thofe precautions which are ufual when great precifion is required. The refult of all thefe has been only a fmall difference in fome of the right afcenfions, which can have little or no influence on the ultimate refults of the calculation, and for which reafon I did not think great exactnefs neceffary in the firft reductions. According to this laft rigorous examination, $I^{\cdot} 5^{\prime \prime}$ are to be deducted from the firft four right afcenfions, and $1 \cdot 5^{\prime \prime}$ to be added to thofe of the Ioth, IIth, I4th, Igth, 2Ift, 23d, 28th, 3oth, and 3 Ift of January, and the Ift of February; and $3^{\prime \prime}$ mult be taken from thofe of the $5^{\text {th }}$ and 8 th of February. With the tranfit inftrument the obfervations were made, different times, with all the five threads; and thefe I always preferred to thofe made with the circle. I ufed thofe by the circle when I failed with the tranfit inftrument; as on the firt four days; and on the $13^{\text {th }}$ of January, when the obfervations were not made with all the five threads, I took a mean of the obfervations made with the circle, and another of thofe made with the tranfit inftrument. The difference between thofe with the former inftrument and thofe with the latter, was never greater than 0.2 in time, except on the

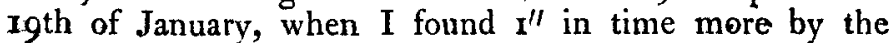
circle. In regard to the declinations, I have found no corrections to be made. Should any aftronomer, for his greater fatisfaction, be defirous to fee the original obfervations, I fhall be bappy to communicate them to him. They will be publifh id in the fixth book of the Specola Aftronomica, together with all my other obfervations made fince 3794 .

XIII. Reflections on the new Primary Planet fuppofed to exift between Mars and Jupiter, and now in all Probability difcovered. By Baron VoN ZACH, Lieutenant-Colonel in the Service of the Duke of Saxe-Gotba, and Director of the Ducal Obfervatory at Seeberg* *.

$\mathrm{T}$

$\mathrm{HE}$ exiftence of a primary planet, which, on account of the faintnefs of its light and fmall fize has hitherto remained undifcovered, was, as far as I know, firft conjectured, or at

* From Monallicb Correfpondenz zur Beförderung der End-und Himme!fkunde, June I son.

leaft 
leaft publicly mentioned, about forty years ago by the immortal Lambert. In his Cofmological Letters on the Univerfe, which appeared at Augfburg in 1761 *, the following remarkable paffage occurs towards the end of the firft letter: "And who knows whether fome planets may not be loft, from the wide fpace between Mars and Jupiter?" This idea was no doubt fuggefted to Lambert by comparing the different diftances of the planets; and he muft foon have found that the diftance between Mars and Jupiter is too great in proportion to the reft. To fill up this vacancy he placed in it a new primary planet; and as it had not been obferved during the courfe of two centuries, that is, fince the invention of the telefcope, he fuppofes it to have been torn from the powerful influence of the fun by a deftructive comet, round which it revolves in infinite fpace as a fatellite; and concludes with this obfervation: "Is the cafe the fame among the celeftial bodies as on the earth, that the ftronger exterminate the weaker; and, are Jupiter and Saturn deftined merely to prey upon others?"

What might tend more and more to confirm aftronomers in the idea of the exiftence of fuch a planet, was a certain relation which they had obferved in regard to the diftances of the fix primary planets from the fun, and which was confirmed, in an unexpected manner, by a feventh primary planet beyond the orbit of Saturn difcovered by Dr. Herichel in $178 \mathrm{r}$. This remarkable relation was firft adopted by profeffor Bode in the fccond edition of his Introduction to the Knowledge of the Starry Heavens, publifhed in $177^{2}$, from profeffor Tilius's tranflation of Bonnet's Contemplation de la Nature, Amft. 1764. To reprefent this relation by fmall numbers, which can be eafily compared if the diftance of Saturn from the fun be divided into roo equal parts, the diftances of the planets from the fun in fuch parts will be as follows:

I. Mercury - 4 fuch parts from the $\odot$

2. Venus $-4+3=7$

3. Earth - $4+2 \cdot 3=10$

4. Mars - $-4+2 \cdot 2 \cdot 3=16$

5. Hera or Juno $4+2 \cdot 2 \cdot 2 \cdot 3=28$

6. Jupiter $-4+2 \cdot 2 \cdot 2 \cdot 2 \cdot 3=52$

7. Saturn - $4+2 \cdot 2 \cdot 2 \cdot 2 \cdot 2 \cdot 3=100$

8. Uranus $-4+2 \cdot 2 \cdot 2 \cdot 2 \cdot 2 \cdot 2 \cdot 3=196,8 \mathrm{c}$. \&c. or more generally the $n^{\text {th }}$ planet, reclioning from the fun, is

*A French tranflation of thefe letters, by Darquier of Toulonfe, was printed at Amfterdam in $\mathbf{r} \delta 0 \mathrm{I}$ by Hult van Keulen, with notes refpeding the lateft difcoveries by J. M. C. Utenhove, of Utrecht. This edition was undertaken in confequence of iny secommondation. 
diftant from that body $4+\left(2^{n-2} \cdot 3\right)$ : or, if we exprefs, as profeffor Wurm has done*, the mean diftance of the firft planet by $a$, the difference between the diftance of the firit and fecond by $b$, and the mean diftance of the earth from the fun by 3 , the mean diftance of the $n^{\text {th }}$ planet from the fun will be $=a+\left(2^{n-2} \cdot b\right)$.

This law is founded on no known theory, at leaft it has never yet been demonftrated matbematically, and is merely deduced empirically from analegical conclufions. In no fcience have the powers of the human mind, merely by mathematical reafoning and the acutenefs of geometrical reflection, produced fo many, fo certain, and fo pure truths as in aftronomy. When we confider the immenfity and exalted nature of the objects on which this fcience is employed, and the infignificance of man and his terreftrial habitation, together with the endlefs variety and concatenation of the celeftial phænomena, which all take place in confequence of one general very fimple law of nature, that of gravity, diffufed throughout the whole creation; and when we reflect what abftrufe mathematical formulæ and methods muft be invented to fubject thefe fo varioufly combined phænomena to calculation, and to obtain a uniform and continual correfpondence of thefe calculations with what actually takes place in the heavens, it muft be acknowledged, that no fcience does more honour to the human genius; that in no fcience have more difcoveries been made à priori; and that no fcience is founded on more incontrovertible proofs than the exalted fcience of aftronomyt.

The mathematical aftronomers, for there are fome who are not fo, do not readily adopt any thing that cannot be matbematically proved. However great, therefore, might be the probability that the above-mentioned relation, in regard to the diftances of the planets, taking it at leaft as an approximation, exifted in nature, there were aftronomers who doubted the confequences of this undemonftrated law, and the exiftence of an invifible planet between Mars and Jupiter.

* Berlin Aftron. Jahre Buche, I790, p. 163.

+ La Place, that eminent analyft, in the preface to his excellent work, fpeaking of the progrefs of the modern chemittry, fays: Et ce ne fera qu'au moment où les loix des atfinités chimiques feront fuffifamment obiervées, pour y appliquer l'analy $f$, que cette fcience (la chimie) anra le degré de perfeetion auquel l'aftronomie s'cit elevée par la decouverte de la gravitation univerfelle. Tbéorie du Mouvernent at de la Figure elliptique des Planèies, 1784 . 
It is worthy of remark, that the aftronomers of no nation but Germany adopted this conjecture in their aftronomical books, or wrote any thing on the fubject. How is this to be accounted for? Does the fpirit of an eminent German, the fpirit of a Kepler, ftill hover over Germany? I do not here mean to affert that the Germans believed unconditionally in the exiftence of this planet, or acknowledged it as proved. Profefior Bode has mentioned it in all his valuable works on aftronomy, and in all the editions of them publifhed fince 1772 ; but he always fpeaks of its exiltence as founded on conjecture or amalogy, and not as a demonftrated truth.

About fixteen years ago I employed myfelf in analogical calculations of the elements of the orbit of this latent planet, as may be feen by the letters I wrote to profeffor Bode from Drefden, in September 1785 , which were printed in the Berlin Aftronomical Almanac for 1789 . But I fpoke of thefe refearches as mere $d r e a m s$, and called my calculations cbimerical. I even ridiculed them, and compared them to the refearches of the adepts who endeavour to find the art of gold-making. In the year 1798, when, in confequence of Lalande's vifit to Gotha, I had the pleafure of feeing my highly efteemed friend Bode, this fubject formed part of our converfation. That worthy veteran Lalande had no great faith in the exiftence of this planet; he has not faid a word of it in any of the three editions of his Aftronomy which have been publifhed: and I ufed to call thofe who entertained a ftrong belief of its exiltence, aftronomical adepts.

In the year 1787 profeffor Wurm was engaged with fimilar thoughts on the poffibility of other planets and comets exifting in our fyftem. Thefe ideas he communicated to the public in the Berlin Aftronomical Almanac for $179^{\circ}$, and in that of the following year, where he extended them to the fyltem of the fatellines. But he obferved at the fame time, that he was far from wihing to make any one adopt his aftronomical vifions, as he exprefsly terms them.

Aftronomers had the greater reafon for being on their guard againft analogical conclufions, as the remarkable inftance of our great mafter may ferve to how that too much confidence muft not be placed in a lively imagination. Poets may be allowed fome latitude in this refpeet; but we muft refufe the fame indulgence to a certain clafs of naturalifts and philofophers, who think they can catch nature in the fippery paths of myfticifm; who fubftitute an uniutelligible jargon for a language generally underftood; and who attempt to explain a difficulty by obfcurity.

Kepler, who often indulged in fuch aftronomical dreams, VoL. XII. 
and gave full fcope to his ardent imagination, thought he had made a great difcovery by fuppofing that the five regular bodies would fit exactly into the vacuity between the fix planets known at that time; and their diftances indeed, according to the lateft obfervations, correfpond very well. with this rule. But unfortunately, as has been remarked by profeffor Wurm, Euclid and Nature left no regular body for Uranus; and I may add, that none remains for Hera: fo that Kepler's ingenious idea falls at once to the ground.

Should the queftion propofed on the difcovery of Uranus be here afked-Why was not this planet difcovered long ago? we might give the fame, anfwer to it as given by Lichtenberg*, who confidered it of the fame kind as that of Lelio's fervant in Leffing's Treafure, who wifhed to know why his father had returned on a certain day, and not a year fooner or later; which he thought would have been much lefs incomprehenfible.

The moft natural way is, as profeffor Bode has done in his Illuftration of Aftronomy, to conjecture that this planet, being fnaller than Mars, and at a confiderable diftance beyond it, reflects too little light from its furface; and hence it has efcaped the keeneft-fighted obfervers. But who knows what the nature of its furface may be? We are acquainted with celeftial bodies which exhibit different colours, fhades of red and green; as for example Mars, and the double ftar $\boldsymbol{\gamma}$ in Andromeda, the light of which increafes and decreafes ; and others which even difappear from our view.

Kant and Wunfch, in their Cofmological papers, affert therefore that this planet does not exift by itfelf, but that it is incorporated with Jupiter; which is therefore of greater fize than it ought to be according to the fuppofed rule, and confequently fupplies the place of two planets. Kant afcribes the frmall fize of Mars, and its want of fatellites, to the fame caufe. But this hypothefis was not neceffary to explain the invifibility of this planet, as it can be done in a much better maniner, and more agreeable to the laws of nature. How long did Uranus remain concealed from our fight! And yet it was not only in the heavens, but, as we now know, was feen and obferved 20, 30, and 90 years before Herfchel's difcovery of it, by a French, a German, and an Englifh aftronomer. How then could profeffor Wunfch, in the fecond edition of his Cofmological Converfations, publifhed in $1791+$, confequently ten years after the difcovery of Uranus, ank the following queftion: "What kind of a body muft that be which, though

$$
\because \text { Güeting. Tafchentuch, } 1783 \text {. }
$$$$
\text { + Vol.i. p. } 599 \text {. }
$$ 
to near, cannot be found by the beft telefcopes, though every fmall fpot in the heavens is every night examined with the greateft diligence? But if this planet hould once be difcovered, or if it be really difcovered, it will be eafily comprehended why, as a telefcopic ftar, it could have remained fo long concealed among the innumerable multitude with which the heavens are covered*. Profeffor Wunfch thinks, that as the fatellites of Saturn and Uranus, which fhine only with a pale faint light, can be feen by means of good telefcopes, this concealed planet might alfo have been feen. But profeffor Wunfch does not reflect, that to fearch for an exceedingly fmall moveable luminous point, that changes its place in the immenfity of the heavens, is much more difficult than to fearch for a fatellite, which always remains in the neighbourhood of its primary planet, and mult even be found in the field of the obferver's telefcope. As profeffor Wunfch is a good mathematician, he may calculate the probability and poffibility of the difcovery of a fatellite and of fuch a planet. It is poffible that this planet, as was the cafe with Uranus; may have been feen feveral times; but it is alfo poffible that it is not always vifible. For, fince it appears only as a telefcopic ftar during the time of its neareft approach to the earth, at its greateft diftance from us it may efcape the beft inftruments and difappear entirely; which renders the finding of it ftill more difficult and uncertain.

All thefe impediments might in part have been forefeen; and it was only by an accident, or fyftematic regulation, that the difcovery of this planet amongtt the immenfe number of telefcopic ftars was poffible. In the year 1787 , when I undertook, at Gotha, a new revifion of the ftarry heavens, my view was to fearch for this planet, to which I was particularly encouraged by the auguft founder of the obfervatory of Gotha. I therefore confined myfelf merely to the zodiacal ftars, and made a catalogue containing the right afcenfion of thefe ftars, under a conviction that it was poffible by thefe means alone to fall upon this concealed planet.

In the autumn of laft year, when I had the pleafure of undertaking a hort aftronomical tour to Celle, Bremen, and Lilienthal, and of fpending a few agreeable weeks in the company of fome of the ableft German aftronomers, thefe

* On the difcovery of Uranus Lalande made the following reflection : Le nombre des étoiles de feptieme grandeur eft fi prodigieux qu'on auroit regardé comme impoffible et inutile de les obferver toutes, et à plufieurs reprifes; cela eût eté cependant néceffaire pour favoir s'il n'y en avoit pas quelqu'un qui eût un mouvement. Epbemer. des Mouv. éleft. vol. viii.

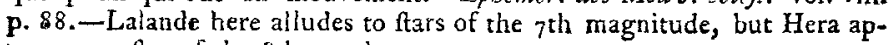
pears as a ftar of the 8 th or 9 th.

E 2

eminent 
eminent men were of opinion that it was not poffible for one or two aftronomers to examine all the telefcopic ftars of the whole zodiac in fearch of this concealed planet. Six aftronomers then affembled at Lilienthal refolved therefore, on the 21ft of September 1800, to eftablifh a fociety of twentyfour practical aftronomers difperfed throughout different parts of Europe, for the exprefs purpofe of fearching out this planet fuppofed to exift between Mars and Jupiter. They elected Mr. Schröter as their prefident; and I had the honour of being chofen their perpetual fecretary. The plan of the foeiety was to divide the whole zodiac among the twenty-four members, each of whom was to have affigned to him, by lot, a zone of $15^{\circ}$ of longitude, and of from 7 to $8^{\circ}$ of north and fouth latitude. Each member was to conftruct a new celeftial chart of his department, comprehending the fmalleft flans, and, by repeated examination of the heavens, to afcertain the true ftate of his diftrict, and whether it contained that wandering body. By this inftitution we entertained hopes that this ftar, which had fo long eluded our refearches, would be at length traçed out. In the name of the fociety I wrote to feveral of the moft celebrated practical aftronomers in Europe, inviting them to concur in this general object; and almoft all of them agreed to the invitation with great readinefs". Some of the members, who have already begun their labours with great diligence, have tranfmitted, for our infpection, very interefting information; and though our infant fociety may be deprived of the honour of firlt difcovering this planet, not only is the fuppofed difcoverer of it among the number of its members, though the uncertain Atate of conveyance by poft or by fea, in confequence of the war, has hitherto prevented us from tranfmitting our invitation to Palermo, but the fociety has already contributed a great deal, and will ftill contribute more, towards correeting our catalogues of the ftars: and as this is not the only objeet of the fociety in the extenfive province of aftronomy, its labours, by being continued, muft be of confiderable utility.

In the month of February, this year (1801), I received a letter from Lalande at Paris, in which he informed me, that Piazzi, aftronomer at Palermo, had difcovered, on the ift of January, a fmall comet in the fhoulder of Taurus ; it appear-

* The only aftronomers who begged to be excufed were profeftor Sniadecki of Cracove, and profeffor Wurm of Blaubeuern. The former, becaufe, the univerfity of Cacow being fuppreffed, he was confequently obliged to leave the obfervatory : the latter, on account of the want of infruments. Rut this difficulty ivas removed by princely munificence. The duke of Gortha fent profelfor Wurm a 7 fett reflector by Herfchel, and the duche's an aftronomical clock. 
ed like a ftar of the 8 th or $9^{\text {th }}$ magnitude, without any nebula or tail : but as nothing elfe was faid of its pofition or courfe, it was not poffible to find it; and therefore, in expectation of more correct information, I paid no further attention to it.

In Airil I received a letter from Bode of Berlin, dated the I $4^{\text {th }}$ of that month, in which he told me that he had received a letter from Piazzi, dated Palermo, January 24, ftating, that on the $x \mathrm{ft}$ of January he had difcovered a fmall comet in $51^{\circ} 47^{\prime}$ right afcenfion, and $16^{\circ} 8^{\prime}$ north declination. On the I Ith of January, from being retrograde, it had become direct; on the $23 \mathrm{~d}$, its right afcenfion was $5 \mathrm{I}^{\circ} 46^{\prime}$, and its northern declination $17^{\circ} 8^{\prime}$. He hoped he ghould be able to obferve it during the whole of February; it was very fmall, like a ftar of the 8th magnitude, and without any nebulous light. Profeffor Bode added: "On reading Piazzi's letter, I was much ftruck with the appearance and motion of this fuppofed comet; and I immediately wrote to him to fend me the fequel of his obfervations. In the mean time I cannot help mentioning that $I$ have found, by a well-known and eafy calculation, that the two obfervations of the ift and $23 \mathrm{~d}$ of January, and the ftationary ftate of the ftar on the I ith of the fame month, agree excellently with the fuppofition that it is not a comet, but perhaps the hitherto unknown planet between Mars and Jupiter, taking its diftance at from 2.75 to 2.80 . What do you fay of it? It is much to be regretted that we have not a third obfervation. But, as the ftationary ftate agrees very well with the given places, it has become to me a matter of great importance. Send me a few words by the next poft refpecting your opinion. I may err, and wifh for information; but the correfpondence is very remarkable. Do you know any more obfervations refpecting this fingular comet?"

On reading this letter, I immediately had recourfe to my old calculations of the years 1784 and 1785 , and thowed to profeffor Pafquich, whowas prefent when I received the letter, that my elements of the orbit of this planet, calculated from analogy in the year 1785 , and inferted in the Berlin Aftronomical Almanac for 1789 , gave as its diftance from the fun $2 \cdot 82$, and as its period of revolution 4.74 years, or 4 years 9 months. Profeffor Bode, from Piazzi's obfervations, had found the diftance 2.75 , and the revolution the fame as $I$ had deduced from analogy, viz. 4 years 9 months. I immediately fent an anfwer to profeffor Bode's letter, and informed him, that my two elements of the orbit of this fo long concealed planet, calculated, provifionally, fixteen years before, amidtt my analogical dreams, and which I had depofited in his hands in a fealed 
note in October 1785 , when I had the pleafure of forming a perfonal acquaintance with this worthy friend at Berlin, correfponded perfectly' with his own, and confequently with thofe of Piazzi. I was therefore not only of opinion that the fuppofed comet might be the invifible planet fo long fought for in vain, but found that Oriani of Milan, from whom I received a letter two days after, entertained the fame opinion, that this ftar was the planet fuppofed to exift between Mars and Jupiter. Piazzi himfelf, even in January, (Piazzi's letter to Oriani is dated on the fame day as that to Bode, viz. the 24th,) informed Oriani that he confidered this ftar, which he firft fuppofed to be a comet, as a real planet. The honour, therefore, not only of having firft difcovered this ftar, but that alfo of having firft afcertained it to be a planet, cannot be refufed to Piazzi ; and one might almoft fufpect (though we can hardly afcribe fuch a motive to him) that he wifhed to retain to himfelf likewife the honour of having firft calculated its orbit, as he communicated his obfervations in fo fparing and imperfect a manner.

Profeffor Bode announced this difcovery and conjecture to the Royal Academy of Sciences at Berlin, and caufed it to be publifhed in the Berlin Gazette of May I2, the Jena Literary Gazette of May 6, and in the Hamburgh paper of the 13 th, from which it was copied into other journals.

Two days after I received profeffor Bode's letter, and before I could return an anfwer I received one from Oriani, dated April 7, in which he fays : "I have received a letter from Piazzi at Palermo, which contains information highly worthy of your attention and of all aftronomers. He writes me, that on the Ift of January 1801 he had obferved a ftar, of the 8th or $9^{\text {th }}$ magnitude, in the fhoulder of Taurus. On the $2 \mathrm{~d}$ of January he found this ftar had advanced about $3^{\prime} 30^{\prime \prime}$ further towards the north, and about $4 \mathrm{~min}$. towards o Aries. The two following days, the $3^{\mathrm{d}}$ and 4 th, he found nearly. the fame motion. On the 5 th, 6 th, 7 th, 8 th, and 9 th, the heavens were fo obfcured that he could make no obfervation. On the Ioth and IIth he again faw the ftar; and afterwards on the $13^{\text {th }}$, I $4^{\text {th }}, 17$ th, I 8 th, I $9^{\text {th }}, 21 \mathrm{It}, 22 \mathrm{~d}$, and $23^{\mathrm{d}}$ of January. From the roth to the I I th its motion, from being retrograde, had become direct. He adds, that on the firft day of obfervation (Jan. 1ft) its right afcenfion was $51^{\circ} 47^{\prime}$, and its declination $16^{\circ} 8^{\prime}$ north. On the $23^{d}$ of January he found R. A. $5 I^{\circ} \cdot 46^{\prime}$, and N.D. I $7^{\circ} 8^{\prime}$. He writes alfo, that he firt announced this ftar as a comet; but, as he alwavs

* Thefe clements had been communicated alfo to the duke of Gotha, to count Bruhl at London, and Köhler at Drefden. 
ablerved it to be without any nebulous ring, and to have a very flow motion, he had feveral times conjectured it might be a planet. This letter, written on the 24 th of January, was unfortunately 7 I days on the road; it was therefore difficult, from the only two pofitions given by Piazzi, to conjecture the place of this wandering ftar after fo long a period. I have, however, endeavoured to take advantage of the circumftance, that on the roth of January the ftar from being retrograde had become direct, and, on the fuppofition of a circular orbit, have found that its diftance from the fun mutt be three femidiameters of the earth's orbit; fo that this ftar may be a new planet, the orbit of which will fall between thofe of Mars and Jupiter. There is reafon to think that the orbit of this planet, like thofe of all the reft, will have a perceptible eccentricity *, and confezuently the hypothefis of a circular orbit, which I fuppofed, muft be improper for reprefenting its motion and gencentric place after fo long a period: we muft therefore wait for the remainder of Piazzi's obfervations, which he no doubt has continued. The heavens with us, fince the receipt of Piazzi's letter, have been always overcaft: you, perhaps, have a $\mathrm{ky}$ more favourable for aftronomical obfervations

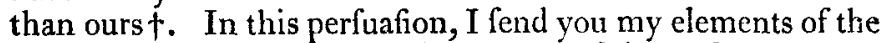
orbit, calculated, as you will fee, from thefe imperfect obfervations, by which you will be able to calculate the planet's place nearly. Heliocent. long. of the ftar at noon, Dec. 3I, 1800, $2^{5} 6^{\circ} 54^{\prime}$; heliocent. motion in long. in 100 days $18^{\circ} 19^{\prime}$. Longitude of the afcending node, $3^{\circ} 8^{\circ} .32^{\prime}$. Inclination of the orbit, $3^{\circ} 5^{\circ}$. But, as already faid, thefe refults are fubject to great doubts; for they are founded only on two very imperfect obfervations, and on the very infufficient hypothefis of a circular orbit. I, however, flatter myfelf that this letter will foon reach you; and, before the ftar be loft in the fun's beams, you will perhaps be fo fortunate with your fuperior, inftruments as to find it, and to be able to give me more correct information refpecting it."

Immediately after I received Oriani's letter, I calculated the place of the planet with its elements, and fearched for it in the heavens on feveral ferene evenings; but, unfortunately, the information had arrived too late. This fmall ftar had already advanced too near to the fun, fo as to be loft in its

* According to my conjectmal calculations, a very great one, 0.14 ; the greateft next to that of Mercury. Time will fhow whether I was ryght.

+ At the bottom of the Thuringian furefts, two hundred per cent. worfe than Milan! How badly my friend was informed refpecting our A pril weather! It is a common proverb at Gotha, that during the brighteft and fineft weather one muft not go abroad without a great coat or unubrella.

$\mathrm{E}_{4}$ 
rays and the vapour of the horizon. I afterwards found that Oriani, in confequence of his great hafte and anxiety to communicate to me the intelligence as foon as poffible, muft have committed an error in the calculation of thefe preliminary elements, particularly iu the 8 , and in the inclination of the orbit. But even had there been no error I fhould not have found this fmall wandering ftar; for when I received the information the obfcurity was too great, and the ftar too near the horizon. Profeffor Bode alfo, as he informed me in a letter dated May I2, had fearched for it feveral evenings, but in vain.

As no hope now remained of being able to obferve this fingular and remarkable body till its return from the fun in Augult or September, I made a calculation of its orbit as well as poffible from fo imperfect and fcanty obfervations, not with a view of finding it again in the courfe of two or three months (for before that time I hoped Piazzi, by continuing his obfervations, would give us better and more determinate data and conclufions), but merely that I might have by me fome conjectures to enable me with better grounds to believe in the actual exiftence of a planet betwcen Mars and Jupiter.

The obfervations given by Piazzi for calculating the orbit are partly imperfect and partly infufficient. Ift, His two obfervations which are known, are only for minutes, and annownced as nearly. 2d, For calculating the oribit of a planet or a comet, tbree obfervations at leaft are neceffary. $3^{d}$, The times of the obfervations are not affigned. In regard to the firlt, we may admit, that at leaft the neareft minutes of the obfervation are given right. In regard to the fecond difficulty, Piazzi perhaps, as already faid, may have purpofely withheld the tbird obfervation, that he might calculate firt himflf the orbit of this planet * ; for he confidered it as fuch before the 24th of Jantary. But if this were the cafe, he betrayed, in fome meafure, his having made a third obfervation; as he mentions that the planet from the Ioth to the IIth of January was ftationary. Oriani and Bode took advantage of this circumftance, and I employed it myfelf to calculate an approximate orbit of this planet from thefe feanty obfervations. The third difficulty was obviated by the following conjectures:

Piazzi, as is well known, is employed in the conftruction

* The celebrated French aftronomer J. N. de l'Ifle went fill further. Having dilcovered, at the obfervatory of Paris, the long announced, long expected comet of 1759 , he ktpt it a long time fecret, obferved it in private, and ordered his pupil Miffier to fay nothing of his difcorery. 
of a large celeftial chart *. He had alfo, in part, the good fortune which I boned to enjoy while preparing my catalogue of the ftars, and with the view of which the Lilienthal Aftronomical Society was formed; and the planet would certainly not have efcaped them, even if it had not been difcovered by Piazzi $\uparrow$. Piazzi is furnifhed at his obfervatory with an excellent tranfit inftrument, and a complete meridian circle by Ramfden, by means of which he no doubt fell upon this fmall wandering ftar. This ftar muft have culminated on the Ift of January, the day when difcovered, about nine in the evening. At that time of the year and hour it is perfect night at Palermo; and therefore Piazzi could very well obferve this fmall ftar, of the 8th or ninth magnitude, with a day telefcope. It was, however, full moon; and as the moon had rifen three hours above the horizon of Palermo, the night muft have been very bright. But the moon was four hours, or about $68^{\prime}$ diftant from the ftar; and this circumftance alone converts my conjecture into certainty, that Piazzi muft have found this fuppofed comet not with a comet-fearcher, but with his meridian inftrument. The above-mentioned right afcenfions of the wandering ftar, converted into time, were confequently the time of its culmination in fidereal time: thefe I again converted into mean folar time, and thus brought out the true moments of the obfervations of the ftar. By thefe, and the obliquity of the ecliptic $23^{\circ} 28^{\prime}$ 10", I have obtained the following data for calculating the prbit :

\begin{tabular}{|c|c|c|c|c|c|}
\hline 1301. & $\begin{array}{l}\text { Mean Time } \\
\text { it T'aler nio. }\end{array}$ & $\begin{array}{l}\text { Geocent. Long. of } \\
\text { the } P \text { an. }\end{array}$ & $\begin{array}{l}\text { Geocent. } \\
\text { Lat. South. }\end{array}$ & $\begin{array}{l}\text { Place of } \odot \\
+20^{\prime \prime}\end{array}$ &  \\
\hline & $\mid \begin{array}{lll}31 & 43^{I} & 35^{l} \\
7 & 16 & 41\end{array}$ & $\mid \begin{array}{llll}1^{5} & 23^{\circ} & 29^{\prime} & 40^{\prime \prime} \\
1 & 23 & 43 & 40\end{array}$ & $\begin{array}{lll}2^{\circ} & 37^{7} & 5 \\
1 & 3^{8} & 0\end{array}$ & $\mid \begin{array}{cccc}9^{5} & 1^{\circ} & I^{\prime} & 40 \\
10 & 3 & 22 & 28\end{array}$ & \\
\hline
\end{tabular}

As the ftar on the Ioth of January became fationary, I found its elongation for that time $7^{\circ} 26^{\circ} 4 \mathbf{I} 4 \mathrm{I}^{\prime \prime}$, and, by means of Keil's propolition, that the tangent of the elongation is equal to the femidiameter of the orbit divided by the fquare root of that femidiameter, + I. I found this femidiameter $=3.07 \mathrm{I}$, and, by Kepler's principle, the revolution

* Laft year he publifhed his large catalogue, comprehending 5500 ftars. + It was really fortunate that Piazzi difcovered his ftar on this day; for, had he fallen upon it eight days later, it is poffible it might have efcaped him; for, as this wandering ftar about that time became ftationary, he would not, from the obfervations of next day, have remarked its motion. It is very fingular that this new planet, if its being fuch be really confirmed, was difcovered and fien in the fhoulder of Taurus, as Uranus was 20 and 1 to years ago. 
$\left(3^{\circ} \circ 7 \mathrm{I}\right)_{\frac{3}{2}}=5.38 \mathrm{I} 7$ years. By the ufual methods I obtained the following approximate elements of the orbit:

Epoch of the mean beliocentric longitude for the commencement of 1801 Long. of the afcending node Mean annual motion Inclination of the orbit ... $\quad\left[\begin{array}{llllll}- & - & 2 & 6 & 54 & 25\end{array}\right.$ Semidiameter of the orbit $3.07 \mathrm{I}$ Synodical revolution - 5.3806

Thofe who attentively confider and compare thefe elements will no doubt remark, that the diftance and periodical time of Piazzi's ftar are exactly the fame as thofe of the celebrated comet of 1770 , the calculation of which gave fo much employment to aftronomers, and the orbit of which Lexel could no otherwife reprefent than in an ellipfe of $5 \frac{1}{2}$ years. Pingré alfo found its diftance $=3.09$, and the period of revolution $5^{\circ} 4$ years *. Burckhardt, who lately obtained the fecond prize propofed on this fubject by the National Inftitute, could not reduce this fingular body from new obfervations into any other than an elliptical orbit of $5 \frac{1}{2}$ years. Was the comet of 1770 the fo long concealed planet? or was Piazzi's ftar the comet of 1770 ? . In either cafe, whether it was a comet or planet, Why was it not oftener feen, or before difcovered? The caufes, fome of which we have already mentioned, may have been various. But to confine myfelf to a probable way of explaining this point, let the reader only look into Schröter's Obfervations on the Comet of 1799 , publifhed in the third volume of his Collections in regard to the lateft Aftronomical Difcoveries $\uparrow$. The moft fingular phænomena of the accidental variable modifications of the nebulous light furrounding the comet, and alfo the well-known atmofpheres of the planets, and even the fun, will be found there explained. In the nebulous light which furrounded the comet of I799, Mr. Schröter obferved not only occafional, but fudden and difproportionably great changes both in the extent and ftrength of the photofphere. Dr. Herfchel not long ago prefented to the Royal Society a paper on the ftructure of the fun, in which this eminent aftronomer explains the folar fpots by fuppofing an elaftic and not luminous gas difengaged from the opake furface of the fun's body, which divides the furrounding luminous fluid or photofphere, by which means we then fee dark parts of the body, which we confider as fpots.

Is it not therefore poffible that we fee ftars at one time

Cometographie, part ii. p. 89.

+ Allgem. Geograph. Ephemerid. vol. iii. p. 432. 
which difappear at another? We are acquainted with many which have periodical changes of light of greater or longer duration; as, for example, thofe numerous changeable ftars called Stellee mirabales. What has become of the celebrated Tycho Brahe's ftar in Caffiopeia of the year ${ }^{1572}$, which at one time hone'as bright as Sirius, and even exceeded Venus and Jupiter when in their perigeum; fo that it could be feen in the day with the naked eye; fince which time not the fmalleft traces of it have been found? We learn by the old chronicles, that in the time of the emperor Otho I. about the year 945, and alfo in I264*, a new and motionlefs ftar appeared between Caffiopeia and Cepheus. Some aftronomers, therefore, conjectured that this might be the ftar of 5572 , which appeared periodically in the courfe of about 300 years + . Had it any affinity with the celebrated ftar difcovered by Kepler in I604 in the foot of Serpentarius, which feemed at one time fo bright that it exceeded in fplendour ftars of the firft magnitude, became invifible next year, and has never fince appeared? What are Herfchel's planetary nebulæ? Did not Schröter $\ddagger$ find that whole tracts of luminous nebulæ difappeared from the heavens? What are our large fire-balls, which move with a velocity a hundred times greater perhaps than that of a cannon bullet, emit a bright light, burft, and then difappear? It is proved that they are bodies belonging to the univerfe, and not to our atmofphere. This was the opinion of Montanari $\S$ in 1676 , who, in his Fiamma volante $\|$, calculates that one of thefe fire-balls, feen throughout all Italy in the above year, was at the height of forty lialian miles. All our readers muft remember the large fire-ball feen in the year 1783 in every part of Europe, and pretty well obferved. It was calculated by fome of the Englifh aftronomers that the height of this immenfe body of fire was 60 Englifh miles, and that its greateft diameter was $1 \frac{1}{6}$ th mile. In feven minutes it would have paffed over a fpace equal to the femidiameter of the earth

Why may not comets appear fometimes luminous and at

$\approx$ Leorit. apud Tychon. Iib. i. p. 44r. Licet. lib. v. cap. 12.

+ See Laplace's hyporhefrs on this fubjet in his Expofit. du Sy/teme du Monde, liv. $\%$. p. 347. an. 7 , the only real edition in quarto acknow ledged by the author.

+ Beytrage, p. 232 .

Halley and Hevelius confidered them alfo as cofmical bodies.

II La Fiamma volante, gran Meteora veduta fopra l'Italia la fera de 31 Marzo 1676, Speculazioni fifiche et aftronomiche efpreffe dal Dott. Geminiano Montanari .... in una Lettera all, 1ll. Ecc. Sgr. Marchefe Federico Gonzaga, Bologna 1676. 95 pages quarto: a very fcarce work, for which 1 am indebted to the kincinets of profeffor Blumeubach, and which Dr. Chladni, who has collected on this fubject with fo much care, was never able to obtain. 
others dark? The comet of 1770 , therefore, might exift fometimes in an opake, and fometimes in a phofphorefcent ftate; and hence perhaps, and from the perturbative power of the larger and more denfe bodies, the unfrequency of their return may be explained. They come back, and we do not fee them; they are prefent, and we do not obferve them. To draw conclufions, from the identity of the elements of the orbit of a body, refpecting the identity of the body itfelf, gives, as all aftronomers know, but a high degree of probability*, among the ninety-one comets, confirmed by only one hypothefis + , which certainly may be true taken directly but not inverfely. Two comets, however, whofe orbits have not the identical fame elements, may be one and the fame body. This, as far as I know, has never been explicitly afferted by any one : but Lexel mentioned it implicitly, when the following objection was made to him on account of the five years elliptical orbit of the comet of 1770 : Since the period of the revolution of this comet is fo fhort, why was it not feen oftener, and long ago ? Lexel was of opinion, and perhaps fo was the great Euler his mafter, under whofe infpection he laboured, that the influence and perturbation of the large body of Jupiter, to which this comet approached very near on the 27th of May $176 \%$, and the 23d of Auguit 1779 , might have entirely changed its orbit $\ddagger$. Burckhardt was of the fame opinion in his memoir written on the fubject of the prize already mentioned.

But how frightful is the mere idea of calculating the perturbation of fuch a body! Would not fuch a calculation exceed the powers of our analyfis? The difficult theory of the moon would be mere elementary calculation compared with the variable orbit of fuch a body. It were to be withed that fo ftriking a phænomenon would produce the neceffity of giving to our calculation, in regard to perturbation, a new direction, that the theory of fo complex an approximation might be more improved, and that the influence of the fucceffive integrations on neglected quantities might be better and more accurately determined. But the geometrician, who can reprefent all the co-ordinates of the motion of each celeftial body in fpeedily approximating feries of fines and cofincs of the angle depending on its real motion, does not, perhaps, exift on our earth.

* Monat. Correfpond. vol. iii. p.4r4.

+ 'The fo called Halley's comet, the fifth and laft obferved return of which took place in 1759 , and which will appear again in 1835 .

+ “M. Lexel penfe, que ton orbite peut avoir été totalement changée par "acticn de Jupiter." Pingré Cometograph. part ii. p. 90. See alfo Mén. de Paris 1776 . p. 648 . 
Many no doubt will confider the tail which, according to Meffier's exprefs obfervation *, attended the comet of 1770 , as a proof that it could not be a planet. But, is it proved that planets cannot have a tail? We bave planets with fatellites, and others without thefe attendants; why therefore fhould there not be planets with tails, to prove, in a vifible manner, that they are nothing elfe than planets? This difference in the appellation originated in the periods of ignorance, and muft now be admitted into our language to diftinguin thofe bodies, the appearance of which is of thorter duration, and which do not remain vifible throughout their whole orbit $\uparrow$, from thofe which are always vifible, except when they approach too near to the fun. The circumftance which feems to be peculiar only to comets, that fome of them move retrograde, while all the planets move direct, is only apparent. The reader is referred to the explanation which Laplace and Lalande have given of this point in regard to the retrograde fatellites of Uranus $\$$. Lalande fays the word retrograde impofes by its expreffion, but in reality is nothing. Kant, in his Allg. Nat. und Tbeorie des Himnels, original edition, publithed in 1755 , conjectured that the retrograde motion of fome comets might be only an optical illufion, like that of the geocentric motion of the planets.

Every newly difcovered object muft have a new appellation. Though a name in itfelf is of no great importance, we have feen in regard to Uranus how difficult it is for all mankind, from the Thames to the Neva, to be unanimous in this refpeet. If the ftar lately difcovered by Piazzi be really the fuppofed planet between Mars and Jupiter, a great and auguft patron of aftronomy, the founder of the obfervatory of Seeberg, gave it, in my opinion, a very appropriate name fifteen years ago. Uranus has afforded us a ftroug right, on the fcore of uniformity, to affign to this new planet, as has been the cafe with the old ones, a name borrowed from the heathen mythology. The duke of Gotha propofed, therefore, that of Hera, "Hpa, or of the deity ftyled by the Romans Juno, the daughter of Saturn, and the fifter and wife of Jupiter § : Jupiter therefore would have his father and grandfather above him, and his wife and children below him.

* Mém. de Paris 1776. p. 597.

+ The new planet, perhaps, is not vifible in apogeum, as already obferved.

$\ddagger$ Allgem. Geograph. Ephemerid. vol. ii. p. 170 and 259. See alfo

Laplace's Expofit. tu Siftème du Monde, p. 342 .

$\S$ Called alfo Saturnia. The duke at firlt propofed Rbea, the wife of Saturn; but this name has aiready been applicd to the Eurth. 
The Greek name Hera is to be preferred to the Latin name Juno, Ift, Becaufe the latter has been already applied to the planet Venus. Pliny fays *, "Infra folem ambit ingens fidus, appellatum Verreris . . . . . . Alii enim Junonis, alii 1fadis, alii matris Deûm appellavere." St. Auguftine t calls Venus, Stellam Junonis; and Apuleius $\ddagger$ fays, "Junonia, immo Veneris ftella cenfetur." Hera is always involved in clouds, and our planet kept itfelf a long time concealed. This name, therefore, will ftill be appropriate even if the new ftar thould not be the fuppofed planet: in that cafe, inftead of the deity we have embraced a cloud $\S$. 2d, Hera is at the fame time the name of a city in Sicily, by which means the difcovery made on that ifland, and the celebrated name of the difcoverer of this eighth primary planet, will be eternized and preferved as long as tradition and hiftory exift on the earth. The city of Hera, fituated, as well as $\mathrm{Pa}$ lermo, on the coaft of Sicily, was called alfo Hybla Minor, and is the fame mentioned by Paufanias, Cicero in his Letters to Atticus, and Antoninus in his Itinerary. In the laft place, Hera is the mother of Vulcan, who has his workthop in the burning mountain of Etna in that inand.

The objection already made in regard to Uranus, that all the planets have Roman and not Greek names, muft be of lefs importance, as the Greek name Oupavos has been retained to that difcovered by Herfchel, though it would have been more agreeable to analogy to have called it Colus. All the old planets, the difcovery of which is loft in the obfcurity of time, may retain their Latin names; but the new planets, the hiftory of the difcovery of which will be handed down to the latelt pofterity, with the names of the difcoverers, ought, by way of diftinction, to have Greek names. What feems here an interruption of analogy will be only harmony. Since the creation, like the Creator, has no bounds, fhould another planet be difcovered beyond Uranus, its hieroglyphic appellation ought to be Greek.

It will be neceffary alfo to invent an appropriate character for this planet. To a new planet we may affign the charaeter of a new metal. This idea has been followed in regard to Uranus; but we have thereby committed an error, or rather eftablifhed a monument of our ignorance refpecting the component parts of platina. It was a much better propofal to diftinguifh this planet by ${ }_{d}^{*}$, the under part of which repre-

\footnotetext{
* Hift. Nat. lib. ii. cap. 6.

+ De Cirırat. Dé, lib. vii. cap. 15.

\$ De Mundo, p. 252 . edit. Bipont.

Nubes et inania captare.
} 
fents a planet, and the upper a fixed ftar: it fhould, indeed, denote a fixed ftar become a planet. But as this charaeter has been already introduced in the Vienna Epbemerides, in order to prevent mifconception it ought to be inverted. The characters of the Earth $t$, and Venus $q$, have the fame affinity, as well as thofe of Mars $\delta$ and Uranus $*$.

POST SCRIPT.

While the laft theet of this paper was printing we received from our worthy friend Dr. Olbers, of Bremen, the following elements of the orbit of Hera, which he calculated in a circle from the obfervations communicated to him by Piazzi :

Semidiameter of the orbit - $\quad-\quad 2.95^{\mathrm{I}}$

Longitude of the afcending $8 \quad-\quad 2^{\mathrm{s}} \quad 21^{\circ} \quad 55^{\prime}$

Inclination of the orbit - - 756

Heliocent. long. Jan. Ift, I801 $\quad-\quad 2745$

Sidereal revolution $\quad-\quad 185^{1} \cdot 6$ days $=5.0694$ years.

Daily heliocent. motion - - $\quad$ II $39^{\circ} 95^{\prime \prime}$

Yearly motion

$71^{\circ} 1^{\prime}$

This orbit is very infufficient, as it is calculated on the bypothefis of a circle: the very imperfect obfervations were only 22 days diftant from each other; and, as Dr. Olbers very well obferves, the lines of fight do not lie advantageoufly. Dr. Olbers is alfo of opinion that thefe elements are not fufficient to calculate a planet fo long before, in order to be able to find it again on its reappearance in the morning in Auguft. In the month of Auguft it will pafs through the whole fign of Cancer, and muft be fought for in the equinoctial point. From the Ift to the 3 Ift of Auguft, a zone of the heavens from II $5^{\circ}$ to $I 30^{\circ}$ of right afcenfion, and from $22^{\circ}$ to $24^{\circ}$ north declination, muft be carefully fearched; for this will be the diftrict of the heavens where the planet will, in all probability, be found in that month.

In the oldeft periods Latin verfes have been invented to denote the order of the planets in regard to their diftance from the fun. Thus, for example, we have the old wellknown verfes:

Saturni atque Jovis Sidus, Mars, Sol, Venus alma, Mercurius, claudit ultima Luna chorum.

On the difcovery of Herfchel's planet, Pcinfinet de Sivry withed to have it called Cybele or Cybelle, after the wife of Saturn, the neareft planet below it; and expreffed the order of the feven planets in the following three Latin verfes:

Ambir Solem Hermes, Venus hunc, mox Terra, Diana,

Mars fequitur. Pergit rex Jupiter. Hune Saturnus.

Omnes hos orbes amplectitur aima Cubelle. 
One of my friends, poffeffed of a poetical vein, has expreffed the order of the planets, now increafed to eight, in the following four lines, and not unhappily :

Mercurius primus: Venus altera: Terra deinde,

Mars pofthac: quintam fedem fibi vindicat Hera.

Jupiter hanc ultra eft. Sequitur Saturnus : at illum

Uranus egreditur, non aufim dicere fummus.

\section{Some Particulars reppecting the new Planet Ceres} Ferdinandea.

I

$\mathrm{N}$ the two preceding papers our readers are put in pofferfion of every thing relative to the difcovery of this planet. The following are fome of the obferved places of the Ceres Ferdinandea, upon its being redifcovered lately, and the times noted are mean time.

$180 \mathrm{r}$.

Dec. 7. Obferved by Dr. Zach of Saxe Gotha, under fome uncertainty of its being the planet.

M. T.

R. A.

Dec. $\mathbf{N}$.

1802 . at $18^{\mathrm{h}} 48^{\circ} 10^{\prime \prime} \quad 178^{\circ} 33^{\prime} 33^{\prime \prime} \quad \mathrm{II}^{\circ} 4 \mathrm{r}^{\prime} 30^{\prime \prime}$

Jan. 5. By Dr. Olbers, at Bremen,

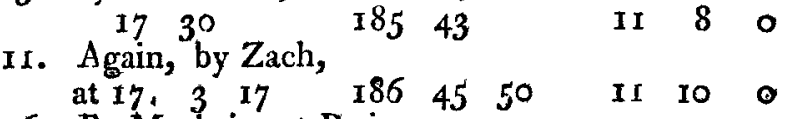

26. By Mechain, at Paris,

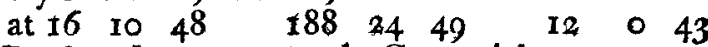

Feb. 3. By the aftronomer royal, Greenwich, $\begin{array}{lllllllll}\text { at } 16 & 11 & 15 & 188 & 43 & 0 & 12 & 39 & 0\end{array}$

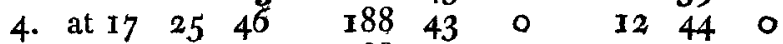

I2. at $15 \quad 4 \quad 12 \quad 188 \quad 30 \quad 0 \quad 13 \quad 33 \quad \circ$

On the $\eta^{\text {th }}$ of February and fubfequent days, it was obferved by Dr. Herfchel at Slough, and alfo by Alex. Aubert, efq. at his obfervatory at Highbury Houfe.

The ftate of the weather at Slough did not admit of Doctor Herfchel's feeing the new planet till Monday night the 8th current, he having previoufly received diftinct notice as to its place from his friend Dr. Mafkelyne, the aftronomer royal, who for the firft time obferved it, like a ftar of the eighth magnitude, on the 4 th current, in the morning. On the $9^{\text {thi }}$ and roth of February at night, Dr. Herfchel again traced the planet, and perceived its motion. It was not however till the morning of the fucceeding day, that through a much clearer air, and at a more favourable altitude, with lefs obftruction 